Dept. of Anatomy \& Histology,

Fac. Vet. Med., Assiut University

\title{
THYROID PICTURE AND GROWTH PERFORMANCE OF EGYPTIAN SAIDI RAMS FED SOME AGRICULTURAL RESIDUES TREATED WITH UREA AND SUPPLEMENTED WITH LIVE YEAST
}

(With 4 Tables and 16 Figures)

\section{By \\ A.E ZAYED, H.A. DAGHASH*, A. ABOU-ELMAGD and G.A. ABD EL-HAFIZ*}

*Department of Animal Production Faculty of Agric. , Assiut University (Received at 1/9/1997)

صورة الغدة الدرقية ومعدل النمو فى الحملان المصريه الصعيديه المغذاه على المقاه

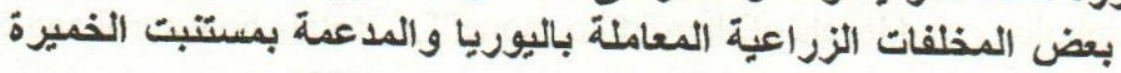

$$
\text { أحدد الزهري زابي ، حسن دغش ، أحد أبو الهجد ، جله عبل الدافظ }
$$

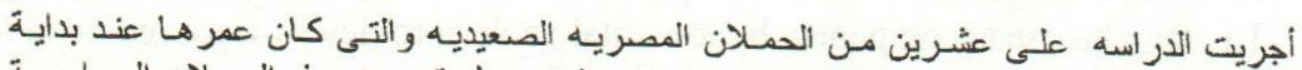

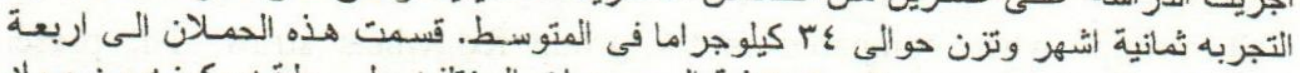

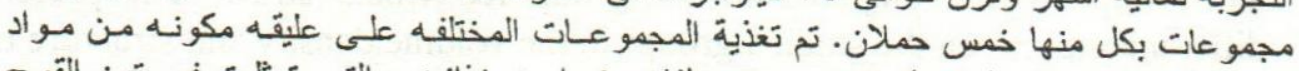

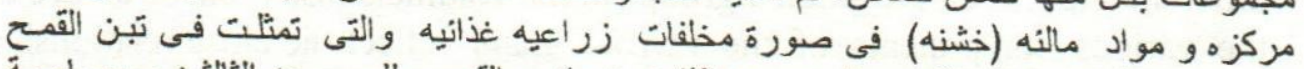

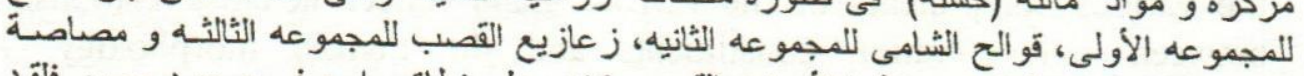

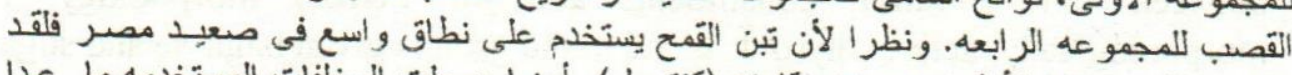

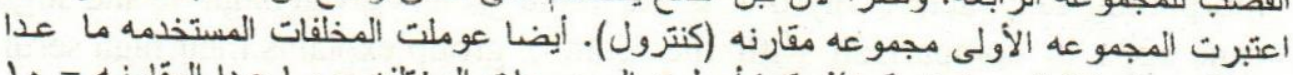

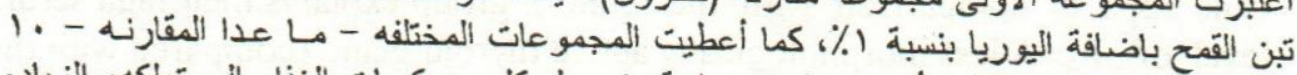

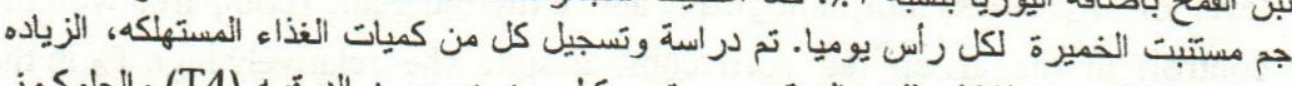

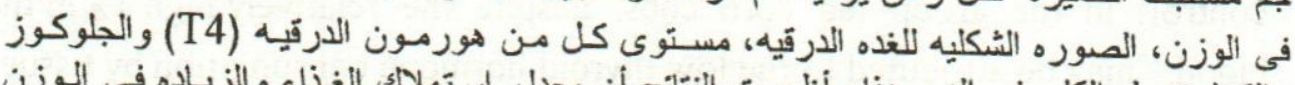

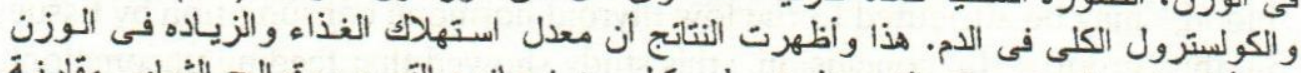

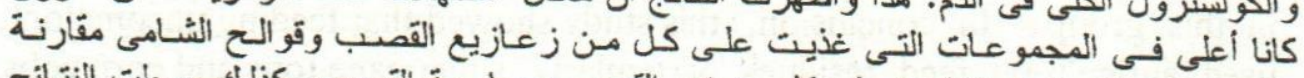

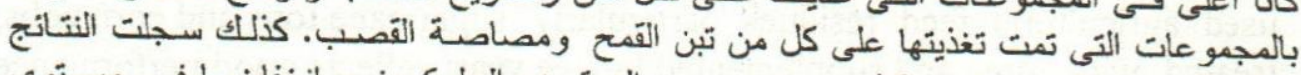

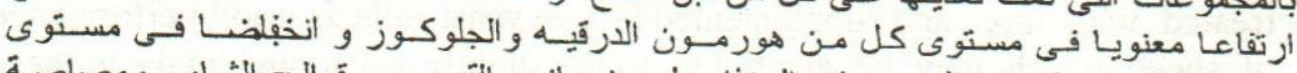

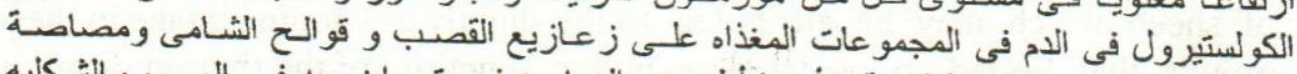

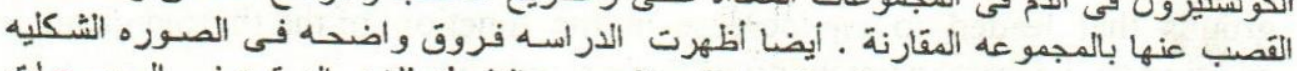

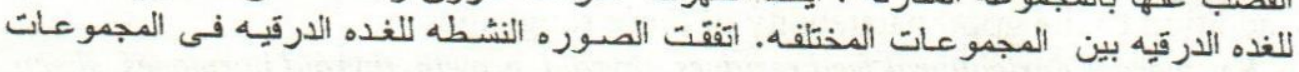




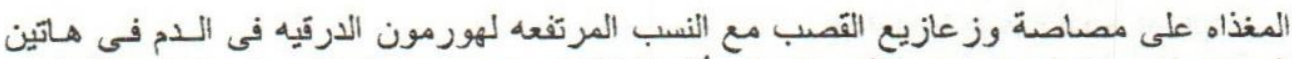

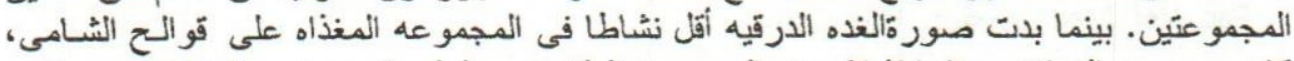

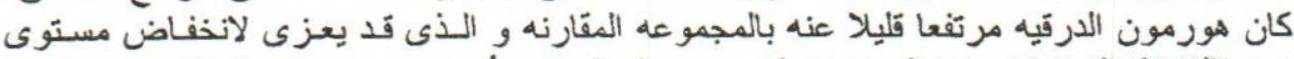

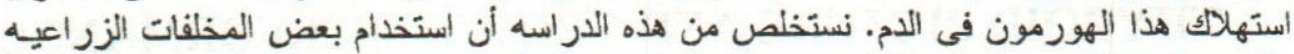

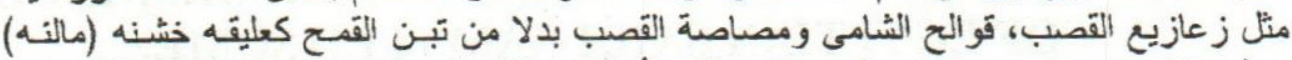

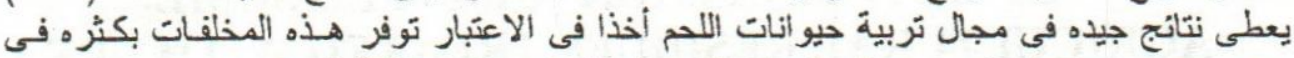

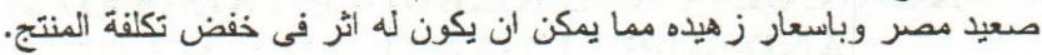

\section{SUMMARY}

Twenty Egyptian Saidi rams aging 8 months with an average body weight of about $34 \mathrm{Kg}$ were used in this study. They were randomly divided into 4 groups, each one consisted of 5 animals. All animals were fed a diet consisting of commertial concentrate mixture and roughages viz; wheat straw, corn cobs, sugar cane tops and bagasse for the first (control), second, third and fourth groups respectively. The used roughages, except wheat straw, were treated with $1 \%$ urea. All animals, except the control, were fed $10 \mathrm{~g}$ live yeast per head per day. Feed intake, weight gain, thyroid morphology and levels of thyroid hormone $\left(\mathrm{T}_{4}\right)$, total cholesterol and glucose as well as $\mathrm{T}_{4}$ uptake and free thyroxine index (FTI) were investigated. The feed intake and weight gain were significantly high in groups given sugar cane tops and corn cobs as compared with the control. A significantly high $\mathrm{T}_{4}$ and glucose accompanied by low total cholesterol levels were recorded in all groups when compared to the group fed wheat straw. The present differences between the studied groups in the volume density and structure of the various components of the thyroid gland reflect the close relationship between the ration constituents and the thyroid morphology. A morphologically active thyroid gland in the groups given bagasse and sugar cane tops in comparison with the control group explains their high serum level of $\mathrm{T}_{4}$. A less morphologically active thyroid gland (compared with the control) in the group fed corn cobs, despite the relatively high $\mathrm{T}_{4}$ in the blood, may be attributed to the low thyroid hormone consumption by tissues in this group. In conclusion, this study showed that feeding uncommonly used agricultural feed residues particularly sugar cane tops and corn cobs, treated with urea and supplemented by live yeast reflects good performance of sheep which may be attributed to the slightly low iodine intake in these groups that leaded to an increase in the function of the thyroid gland in addition to the good palatability of these roughages.

Key words: Agricultural feed residues, thyroid, growth, thyroid hormones, sheep. 


\section{INTRODUCTION}

Trials are still conducted to find other feed sources to replace the commonly used roughages. Agricultural feed residues such as straws, stovers, corn cobs, sugar cane tops and bagasse are found in large amount in Egypt. Because these residues are fair in protein and other essential feeding requirements, many investigators (Gihad et al., 1989; Habeeb et al., 1995; Abdel-Ghani et al., 1995) recommended the addition of urea and live yeast to improve their nutritive value.

The ration composition and its relation to growth performance rate as well as the endocrine functions has received a great attention for long time (Watkins et al., 1982; Schalach and Cree, 1985; Burger et al., 1987). Some authors recorded that energy and protein intake in human and animal species induces changes in growth performance and plasma levels of thyroid hormones (Watkins et al., 1982; Schalach and Cree, 1985; Burger et al., 1987; Beer et al., 1989), plasma protein and creatinine (El-Homosi and ElHafiz, 1982; Hoogwert et al., 1986; El-Masry et al., 1989; Ganong, 1995).

Understanding the steps in the biosynthesis of the thyroid hormones is essential for rational control of thyroid function. Biosynthesis is usually considered from the standpoint of iodine metabolism, because $65 \%$ of the thyroxine molecule is iodine. Furthermore, disorders in thyroid hormone secretion are more likely to be associated with excess or difeciency of iodine rather than of tyrosine or protein (James et al., 1971). Benifit of using agricultural feed residues may throw light on the problem that faces sheep growth and performanc in our country.

\section{MATERIALS and METHODS}

Twenty apparently healthy Saidi rams aging 8 months and weighing about $34 \mathrm{~kg}$ were used. They were randomly divided into four groups, each one is formed of five rams. The roughages "agricultural residues" were fed ad-libitum to all animals under study while the commercial concentrate mixture was given in a constant amount ( $500 \mathrm{~g} / \mathrm{head} /$ day).

The given agricultural residues were represented by wheat straw for the first group (group1), corn cobs for the second group (group2), sugar cane tops for the third group (group3) and bagasse for the fourth one (group4). Because wheat straw is commonly used in upper Egypt, group1 has been considered as a comparing group. The used roughages, except wheat straw, were treated with $1 \%$ urea. Animals of groups $2,3 \& 4$ were 
fed $10 \mathrm{~g}$ live yeast per head per day. The chemical composition and the nutritive values of the used rations are given in Table (1).

The experiment was continued for 135 days, then after,four animals were slaughtered from each group and blood samples were collected from all animals. The thyroid glands were obtained and prepared for light and electron microscopical examination. For light microscopy, the samples were fixed in Bouin's solution, dehydrated and embedded in paraplast. Paraplast sections (5-7 $\mu \mathrm{m}$ thick) were stained with Haematoxylin and Eosin (H\&E). For electron microscopy, small pieces of the thyroid glands were fixed in paraformaldehyde-gluteraldehyde mixture (Karnovesky, 1965). Washing by 3 successive changes of $0.1 \mathrm{M}$ phosphate buffer $(\mathrm{Ph} 7.3)$ was performed before the materials were osmicated $\left(1 \% \mathrm{OsO}_{4}\right)$. The samples were then dehydrated and embedded in a mixture composed of Epon and Araldite as described by Mollenhauer (1964). Semithin sections were cut and stained with tuloidine blue. Ultrathin sections were mounted on cupper grids, stained with uranyl acetate and lead citrate (Reynolds, 1963) and examined in a Joel $\mathrm{EM}$ at the electron microscopical unit of Assiut University.

Morphometrical measurements including volume percentages of interstitial tissue, follicular colloid and follicular epithelial cells as well as follicular epithelial cell-height were measured using image analysis system (Leica Q500).

Serum levels of glucose and total cholesterol of the studied animals were determined using Kits supplied by Sklavo (Italy). In addition serum levels of $T_{4}$ and $T_{4}$ uptake were measured using CEDIA $T_{4}$ homogenous enzyme immunoassay (BM/Hitachi 704).

The free thyroxine index (FTI) as recommended by the American Thyroid Association (1987) was calculated using the following equation:

$$
\text { FTI }=\frac{\left(\mathrm{T}_{4}, \mu \mathrm{g} / \mathrm{dl}\right) \times \mathrm{T}_{4} \text { uptake } \%}{\text { Mean } \mathrm{T}_{4} \text { uptake } \%}
$$

The mean $T_{4}$ uptake refers to the mean \% of $T_{4}$ uptake of the normal range distribution.

Results were subjected to analysis of variance using general linear model (GLM) procedure of SAS (1987) for personal computer, by one-way analysis of variance. Whenever a significant difference was detected, means 
were separated by Least Significant Differences (LSD) according to Steel and Torrie (1980).

\section{Table 1:}

Chemical composition and nutritive values of the experimented ration components*

\begin{tabular}{|l|c|c|c|c|c|}
\hline \multicolumn{1}{|c|}{ Item } & CFM & $\begin{array}{c}\text { Wheat } \\
\text { straw }\end{array}$ & $\begin{array}{c}\text { Corn } \\
\text { cobs }\end{array}$ & $\begin{array}{c}\text { Sugar cane } \\
\text { tops }\end{array}$ & Bagasse \\
\hline Chemical composition. (\%) & & & & & \\
- Organic matter & 92.92 & 84.57 & 95.36 & 86.41 & 97.91 \\
- Crude protein & 20.49 & 03.74 & 11.26 & 13.25 & 09.90 \\
- Crude fiber & 05.26 & 32.87 & 25.26 & 31.96 & 35.60 \\
- Ether extract & 06.95 & 01.85 & 02.55 & 01.65 & 01.78 \\
- Nitrogen free extract & 60.22 & 46.11 & 56.29 & 39.55 & 50.63 \\
- Ash & 07.08 & 15.43 & 04.64 & 13.59 & 02.09 \\
Nutritive values (\%) & & & & & \\
- TDN (total digestable nutrients) & 71.74 & 41.36 & 57.70 & 62.66 & 60.65 \\
- DE* (digestable energy) & 03.16 & 01.82 & 02.54 & 02.76 & 02.67 \\
- DCP (digestable crude protein) & 14.54 & 00.92 & 06.27 & 09.44 & 05.51 \\
\hline
\end{tabular}

* Caculated on dry matter basis.

- Concentrate feed mixture (CFM) consisted of corn (45\%), cotton seed meal (20\%), wheat bran

$(32 \%)$, limestone $(2 \%)$ and mineralized salt $(1 \%)$.

* Digestable energy (DE) calculated as $1 \mathrm{~kg} \mathrm{TDN}=4.4 \mathrm{M} \mathrm{cal} / \mathrm{kg}(\mathrm{NRC}, 1985)$.

\section{RESULTS}

The growth performance of saidi rams of the different groups is demonstrated in table (2) and fig. (11). There was an increase in the daily body weight gain in groups fed corn cobs, sugar cane tops and bagasse than that fed wheat straw. This increase was significant $(\mathrm{P}<0.01)$ in the groups given corn cobs and sugar cane tops in comparison with group 1 fed wheat straw. The one fed sugar cane tops revealed the highest average of the final body weight $(49.0 \mathrm{~kg})$, followed by the group given corn cobs $(47.8 \mathrm{Kg})$, while group 1 which fed wheat straw had the lowest average final body weight $(44 \mathrm{~kg})$.

The daily average of feed intake (Table 2) of groups given sugar cane tops and corn cobs was significantly higher $(p<0.01)$ than that fed wheat straw and bagasse, neverthless, the feed consumption was the heighest in rams fed sugar cane tops (Table 2). Moreover, the feed effeciency (Table 2 and Fig.12) (g ration/g weight gain) was relatively low in the groups with significantly $(\mathrm{P}<0.01)$ high average daily feed intake. 
The blood analysis for serum level of $\mathrm{T}_{4}$ and $\mathrm{T}_{4}$ uptake as well as the calculated FTI is demonstrated in table (3). Rams fed bagasse recorded a significantly $(\mathrm{P}<0.01)$ high value of $\mathrm{T}_{4}$ in comparison with the other experimented groups (Fig.13). The group given sugar cane tops showed a significantly $(\mathrm{P}<0.05)$ high $\mathrm{T}_{4}$ than that of groups fed wheat straw and corn cobs. Concerning the total cholesterol level in blood (Table 3 and Fig. 14), there was no significant variation between groups fed corn cobs, sugar cane tops and bagasse, despite they were significantly low $(\mathrm{p}<0.01)$ than that given wheat straw (control). On the contrary the serum glucose level (Table 3 and Fig.14) was significantly lower $(p<0.01)$ in control group when compared with that measured in the other groups which were not significantly different.

\section{Thyroid morphology:}

In control group (fed wheat straw), the histomorphological picture and the morphometrical measurments demonstrated that this group had the features of a moderately active thyroid gland. The volume percentage of both follicular colloid and interstitial tissue measured about $22 \%$ and $29 \%$ of the whole gland respectivily (Table 4 and Fig. 15). The thyroid follicles (Fig. 1) were round, oval or irregular in outlines. The follicular cells were columnar in shape measuring about $14 \mu \mathrm{m}$ in height (Table 4 and Fig. 16). They had convex apical borders with their nuclei located mostly in the apical half of the cells. Ultrastructurally (Figs. $2 \& 3$ ), the pronounced cell organelle was the rough endoplasmic reticulum (RER) which occupied large area of the cell cytoplasm. It consisted of anastomosed dilated saccules filled with fine granular substance of low electron density. The apical cytoplasm contained many fine electron-dense granules. Some electron-dense granules of different sizes were demonstrated either in the apical cytoplasm or in between the dilated cisternae of the RER. In the supranuclear region, well- developed Golgi-apparatus was located in close association with the RER. Numerous cristae-type mitochondria of variable shape, mostly elongated, appeared forming RER-mitochondria complexes. Sometimes, they were found in groups in the basolateral cytoplasm and in close association with lysosomal structures. The nuclei showed irregular outlines and contained eccentrically located nucleoli, sometimes attached to the nuclear membrane. The apical borders of the follicular cells appeared convex, carried few short microvilli and endocytotic pits. Apical cytoplasmic protrusions could be seen. 
The group fed corn cobs showed the features of decreased thyroid activity compared with the control one. The volume percentage of the interstitial tissue recorded about $24 \%$, while the follicular colloid measured about $40 \%$ of the thyroid gland (Table 4 and Fig. 13). The thyroid follicles (Fig.4) were mostly rounded or oval in shape and distended with colloid material. The follicular cells were cuboidal or low columnar measuring $8.13 \mu \mathrm{m}$ in height (Table 4 and Fig.14). The fine structure of the follicular cells (Fig. 5) showed a marked decrease in the cytoplasmic area occupied by the RER, but it appeared in the form of dilated, interconnecteed saccules scattered in the basal and perinuclear areas. The apical surface of the cells was flat carrying few short microvilli without cytoplasmic protrusions. The Golgi-apparatus was ill-distinct and the mitochondria were remarkably decreased in number. The apical cytoplasm contained some small electron dense granules. Large colloid droplets of variable size were sometimes observed in the cytoplasm.

In the group given sugar cane tops, thyroid activity appeared to be similar or slightly higher than that of the control one. In this group, the volume percentage of the interstitial tissue represented about $20 \%$ and the follicular colloid measured about $29 \%$ of the whole thyroid gland (Table 4 and Fig.15). The thyroid follicles (Fig.6) were round or oval containing moderate amount of thyroid colloid. The follicular cells were mostly columnar measuring $14.66 \mu \mathrm{m}$ in height (Table 4 and Fig. 16), with rounded centrally located nuclei. Most cells showed apical bleb-like structures. Ultrastructurally (Figs.7\&8), the area occupied by the RER was relatively large. It consisted of isolated, sometimes interconnected and moderately dilated cisternae distributed all over the cytoplasm. Relatively high number of mitochondria were observed in association with the RER. Numerous round, small-sized dense granules were observed mostly in the apical cytoplasm. Electron-dense granules of lysosomal nature were also demonstrated in the cytoplasm. Apical cytoplasmic protrusions of variable form and shape were frequently seen invading the follicular colloid and containing fine electrondense granules.

In group fed bagasse, the morphological observation and morphometrical results revealed signs of increased thyroid activity compared with those of the control group. The volume percentage of the follicular colloid was clearly decreased and became $11.19 \%$, while the interstitial tissue expanded to occupy about $33 \%$ of the whole thyroid gland (Table 4 and Fig.15). The follicular form of the thyroid parenchyma disappeared and replaced by labyrinth-form structures which were composed of 
interconnected tubules and acini (Fig.9). The follicular cells were tall columnar measuring $18.78 \mu \mathrm{m}$ in height (Table 4 and Fig.16). The majority of cells contained oval variably situated nuclei with prominent nucleoli. The apical border of the cells was irregularly protruded into the follicular colloid. In comparison with the control group, the fine structure of the follicular cells (Fig.10) displayed well-developed network of cisternae or lamellae of RER filling most of the cell cytoplasm. Their surfaces were covered by high number of ribosomes. Also there was a remarkable increase in cytoplasmic free ribosomes. Active endocytosis in the form of endocytotic pits and fine vesicles filled with electron-dense material resembling that of the thyroid colloid was demonstrated in the apical cytoplasm. Lysosomal bodies of variable size containing homogenous electron-dense substance and eccentrically located vesicles filled with electron lucent material were observed in the apical cytoplasm. The cells showed well-developed Golgiapparatus located in a supranuclear position. The apical border regularly protruded within the colloid and carried numerous microvilli of variable length. Mitochondria were observed in the form of groups in between the network of the RER and in close contact with it. The oval nuclei contained prominent eccentrically located nucleoli. Some nuclei appeared irregular with few indentations of variable depth.

\section{DISCUSSION}

The present investigation showed that the feed intake of corn cobs and sugar cane tops is significantly higher than the other used rations. This high feed intake was accompanied by good feed effeciency. The previousely mentioned high feed intake could be attributed to the stimulating effect of relatively low iodine intake on the thyroid gland which eventually improved metabolic activity due to secretion of optimal level of thyroxine. In the same concern, James et al. (1971) mentioned that low-iodine diets induce increased function of the thyroid. In addition, this was helped by a good palatability of these rations, that can be explained by the notion of El-Ghamry and Badawi (1965) that the diet constituents exert a remarkable effect on the appetite. Our results also revealed that the growth performance of the groups fed sugar cane tops, corn cobs and bagasse is relatively better when compared with that of the group fed wheat straw (control). This high growth performanc may be due to the differences in the estimated nutritive values of the rations used, where the TDN, DE and DCP percentages are markedly high in sugar cane tops, bagasse and corn cobs than those of wheat straw. 
This was greatly augmented by the stimulation of thyroid gland with eventually increased thyroxine level.

In accordance with El-Saadany (1991) and Mattar et $\underline{\text { al }}$ (1995), addition of urea and live yeast improved the nutritive value of the used rations. Urea as a non-protein nitrogenous source can be converted by microbial activity within the ruminant stomach to amino acids (Banks, 1981). Live yeast supplementation may elevate the fermentative process within the ruminant stomach. Bailey and Balch (1961) and Banks (1981) stated that the volatile fatty acids which are the results of microbial degradation of cellulose and its subsequent enzymatic digestion, contribute approximately $70 \%$ of the
ruminant daily energy needed.

The current study pointed to significant differences between the treated groups in the serum levels of thyroxine, total cholesterol and glucose. In the same respect, Ganong (1995) reported that the diet composition has a clear-cut effect on the concentration of thyroxine in the blood. The present work revealed that the thyroxine level and the FTI are relatively high in the groups fed corn cobs and sugar cane tops, and markedly high in the group fed bagasse when compared with the control one. Ganong (1995) reported that the FTI is an index of the amount of the free thyroxine (physiologically active form) in a specimen. The present slight increase in the serum thyroxine level was also accompanied by a significantly high body weight gain particularly in groups fed corn cobs and sugar cane tops. These findings support the previous statement of King and May (1984) and Guyton (1991) who mentioned that greatly increased thyroid hormone production almost decreases the body weight, and greatly decreased hormone production almost increases the body weight. Nevertheless the authors added that these effects are likely to occur in this slight increase because the thyroid hormone in this condition eventually improve the metabolic activity with consequent increase in the animal appetite.

The present work indicated that groups with high thyroxine level are characterised by a significant increase in glucose level and decrease in total cholesterol level in the blood. This agrees with the statement of Ganong (1995) and Guyton (1991) who mentioned that the increase in the basal metabolic rate (high thyroxine level) is accompanied by a drop in the plasma total cholesterol level and an increase in the glucose level. This may be due to increase the formation of low density of lipoprotein receptors on liver cells resulting in removal of total cholesterol from the circulating blood, while the increase in glucose level can be attributed to increase in the rate of absorption of carbohydrates from the gastrointestinal tract. In addition, 
increase the glucose level in the blood may be a result of increase the formation of propionic acid in the ruminant stomach due to fermentative process (Banks, 1981).

Present differences between the studied groups in the volume density and structure of the various components of the thyroid gland reflect clearly the close relationship between the ration composition and the thyroid morphology. These results agree with the notion of Badawi and El-Ghamry (1965) who mentioned that there is an intimate relation between the diet constituents and the endocrine function. Moreover, our findings support the statement of Kalisnik (1981) and Panciera et al. (1990). They reported that the activity of the thyroid gland is reflected in the appearance of the follicle. An active follicle has tall follicular epithelium and relativelly small amount of colloid, whereas an inactive follicle has short epithelium and a large amount of colloid. According to the previous statement and our morphometerical and morphological results the thyroid activity in the different groups can be arranged -compared with the group 1 fed wheat straw- into less active thyroid in corn cobs-fed group, relatively more active in sugar cane tops-fed group and highly active gland in bagasse-fed group. This arrangement is supported by the fine structure of the thyroid follicular cells in the different groups. The degree of development of both RER and Golgi-apparatus, the number of electron dense granules, occurance of apical endocytotic vesicles and pits as well as the coated vesicles have been used by several authers to identify the thyroid activity (Wissing, 1963; Wetzel et al., 1965; Seljelid, 1965, 1967; Abou-Elmagd etal., 1995). Increase of the population of the cytoplasmic vesicles, colloid droplets and dense granules have been commonly regarded as indicators of increase the thyroxine release from the thyroid gland (Wollman et al., 1964; Wetzel et al., 1965), particularly the electron-dense granules have been considered as lysosomal bodies rich in acid phosphatase and site of thyroglobuline degradation (Fujita et al., 1980; Fujita, 1988; Ericson and Nilsson, 1992; Tachiwaki and Wollman, 1990; Maile, 1995). The well-developed RER and Gogi-apparatus reflect an increase in the colloid synthesis and thyroxine secretion as mentioned by Wissing (1963); Wetzel et al. (1965) and Abou-Elmagd et al. (1995). Moreover, occurrance of the apical vesicles, coated vesicles and pits which take up the iodinized thyroglobuline (Bernier-Valentin et al., 1990) suggests that lysosomal formation and endocytosis of colloid are actively taking place in the thyroid follicular cells (Maile, 1995). In addition, the increase of the volume density of colloid which was accompanied by the decrease of the epithelial height in the less active thyroid gland of group fed corn cobs agrees 
with the explanation of Gerber et al. (1987) who stated that the iodine metabolism of these follicles proceeds very much slower than the normal follicle.

Regarding the correlation between the thyroid morphology and FTI, the group fed bagasse showed a marked increase of FTI accompanied by a morphologically very active thyroid gland and low weight gain. This can be attributed to an increase in the synthesis and the secretion of the thyroid hormone as a result to the continuous consumption of this hormone by tissues. Moreover, although the group given corn cobs demonstrated a relative increase in the FTI and a relatively high body weight gain, the thyroid gland was morphology less active compared with the control. The rate of thyroid hormone secretion raises to equal the rate of consumption (Guyton, 1991). The present decrease in thyroid activity may be due to a low rate of the thyroid hormone consumption in such group, where the recorded $\mathrm{T}_{4}$ uptake was relatively low compared with the control.

In conclusion the present study indicated that using the tested agricultural feed residues supplemented with urea and live yeast in feeding rams resulted in an increase in the thyroid activity, an improvement of growth performance and a better feed effeciency. Within these agricultural feed residues, the sugar cane tops gave the best results, followed by corn cobs and lastly the bagasse. This may be mainly attributed to the stimulating effect of relatively low iodine intake which stimulates the thyroid gland to give an optimal level of thyroxine necessary for the different metabolic activities which improve the performance and growth of sheep.

\section{LEGENDS}

Fig. 1: Semithin section of the thyroid gland of wheat straw-fed group showing variably shaped thyroid follicles lined by columnar cells and containing moderate amount of follicular colloid. Toluidine blue. $\mathbf{x}$ 100.

Fig. 2: Electron micrograph of the follicular cells of the wheat straw-fed group demonstrating many RER cisternae, large number of mitochondria (M) of variable shape and some apical lysosomal bodies (arrows). Numerous endocytotic pits and vesicles are seen under the apical border. Arrow head indicates the protruded apical cytoplasm carrying few short microvilli. Follicular colloid (C). $\mathrm{x}$ 6700 . 
Fig. 3: Electron micrograph of the follicular cells of the wheat straw-fed group showing apical portions of follicular cells filled with RER cisternae and Golgi-apparatus (G) in a supranuclear position. Arrow indicates electron-dense lysosomal body. x 6700 .

Fig. 4: Semithin section of thyroid gland of corn cobs-fed group. The thyroid follicles are mostly rounded or oval in shape and distended with follicular colloid. the lining epitheium is low columnar or cuboidal in shape. Toluidine blue. $x 100$.

Fig. 5: Electron micrograph of the follicular cells in the corn cobs-fed group. The RER is represented by small number of dilated interconnected saccules. The apical border appears mostly smooth with few microvilli (arrow head). Mitochondria (M), intracellular colloid droplets (D) and follicular colloid (C). x 6700.

Fig. 6: Semithin section of the thyroid gland of sugar cane tops-fed group. The thyroid follicles are round or oval in shape containing moderate amount of follicular colloid and lined by columnar cells. Most cells carry apical bleb-like structures (arrow heads). Toluidine blue. x 100 .

Fig. 7: The apical portion of follicular cells showing irregular forms of cytoplasmic protrusions invading the follicular colloid (arrows). Many small electron-dense vesicles are seen (arrow heads). Follicular colloid (C). x 6700 .

Fig. 8: Electron micrograph of the follicular cell of the sugar cane tops-fed group showing many RER cisternae scattered throughout the cytoplasm, large number of mitochondria (M), Golgi-apparatus (G) and relatively numerous fine electron-dense granules (arrow heads). Arrow indicates the presence of lysosomal body. $x 6700$.

Fig. 9: Semithin section in the thyroid gland of bagasse-fed group. The follicular form of the thyroid parenchyma disappeared and replaced by labyrinth-form structures lined with tall-collumnar cells. Tuloidine blue. $x 100$.

Fig. 10: Electron micrograph of the follicular cells of bagasse-fed group showing well-developed network of RER and free- and polyribosomes. Numerous endocytotic vesicles (empty arrow) and apical pits (arrow head) can be seen. Large-sized lysosomal body (L) is found in the apical cytoplasm. Many mitochondria (M), Golgiapparątus (G) and centriole (arrow) are also demonstrated. x 6700 


\section{REFERENCES}

Abdel-Ghani, A.A., El-Barody, M.A.A. and Saad, O.A.O. (1995): Milk yield and composition, blood metabolites and rumen activity as affected by different levels of Saccharomyces cerevisiae plus growth medium supplementation in Egyptian buffaloes. 5th Sci. Conf. Animal Nutrition. Esmailia Univ. Vol. 1: 115-128.

Abou-Elmagd, A. Moustafa, M. N. K. Lincoln, G. A. and Hassan, A. H. $S$. (1995): Light and electron microscopical studies on the thyroid gland of sheep after melatonin administration. 1st International Conf. On Electron Microscopy, Advances In Research In Different Fields Of Science, Ismailia Univ.

Badawi, H.M. and El-Ghamry, M.I. (1965): The influence of difeciency of vitamins B1, folic acid, B12 and whole B-complex on food intake, growth, endocrine weight and blood picture in mature male rats. Zentralblatt für Veternärmedizin Reihe A, band 12, Heft 4: 405-413.

Bailey, C.B. and Balch, C.C. (1961): Saliva secretion and its relation to feeding in cattle. Brit. J. Nutr. 15:371.

Banks, W.J. (1981): Applied Veterinary Histology. Williams \& Wilkins, 428 East Breston Street, Baltimore, MD 21202, USA.

Beer, S.F., Birchane, P.M.M., Bloom, S.R., Clark, P.M., Hales, C.N., Hughes, C.M., Jones, C.T., Marsh, D.R., Raggatt, P.R. and Findlay, A.L.R. (1989): The effect of a 72-h fast on plasma levels of pitutary, adrenal, thyroid, pancreatic and gastrointestinal hormones in healthy men and women. J. Enocin. 120: 337.

Bernier-Valentin, F., Kostrouch, Z., Munari-Silem, Y. and Rousset, B. (1990): Coated vesicles from thyroid cells carry iodinated. thyrogobulin molecules. J Biol. Chem. 265: 17373-17380.

Burger, A.G., O'Connell, M., Scheidegger, K., Wood, R. and Danforth, E. Jr. (1987): Monodeiodination of triiodothyronine and reverse triiodothyronine during low and high caloric diets. J. Clin. Endocrin. \& Metab. 65 (5): 829.

Committee on Nomenclature of the American Thyroid Association (1987): Revised Nomenclature for Tests of Thyroid Hormones and Throelrelated proteins in serum. Clin. Chem. 33: 2114-2119.

El-Ghamry, M:I. and Badawi, H.M. (1965): Levels of thyroid and thyrotropic hormones in blood of rats after difeciency of vitamins B1, $\mathrm{B} 12$, folic acid and B-complex as a whole. Zentralblatt für Veternärmedizin Reihe A, band 12, Heft 2: 189-192. 
El-Homosi, F.F. and El-Hafiz, G.A.A. (1982): Reproductive performance of Ossimi and Saidi sheep under two prepubertal planes of nutrition. Assiut Vet. Med. J. 19: 59.

El-Masry, K.A., Aboulnaga, A.I. and Marai, I.F. (1989): Concentrations of cortisole, protein and lipids in goats as affected by season, sex and lactation. Proc. 3 Alexandria, Egypt, Vol. I, P 469.

El-Saadany, F. (1991): Utilization of economical sources of nutrients in animal nutrition. Ph.D. thesis, Fac. Agric. Cairo Univ.

Ericson, L.E. and Nilson, M.C. (1992): Structural and functional aspects of the thyroid follicular epitthelium. Toxical Lett. 64/65: 365-373.

Fujita, H. (1988): Functional morphology of the thyroid gland. Int. Rev. Cytol. 113: !45-185.

Fujita, H., Tamura, S., Takano, T., Ishibashi, S. and Tanaka, T. (1980): Fine structural changes in aging mouse thyroid. J. Gerontal 35: 3-15. Ganong, W.F. (1995): Thyroid gland in : Review of Medical Physiology. 7th Ed., Appleton and Lange California, Libraire du Liban P.O. Box 945, Beirt, Lebanon. P. 290-305.

Gerber, H., Peter, H.J. and Studer, H. (1987): Age related failure of endocytosis may be the pathogenetic mechanism responsible for 'cold' follicle formation in aging mouse thyroid. Endocrinology 120: 1558-1764.

Gihad, E.A., Abdel-Gawad, A.M., El-Nouby, H.M., Gomaa, I.A. and Mohamed, A.H. (1989): Digestability and acceptability of ammoniated rice straw by sheep. 3rd Egyptian-British Conference on Animal, Fish and Poultry Production, 7-10 Oct., Alex. Univ.

Guyton, A.C. (1991): The thyroid metabolic hormones. In: Textbook of Medical Physiology. 8Th Ed. W.B. Sounders Company, Harcourt Brace Jvanovich, Inc. Philadelphia, London, PP 831-841.

Habeeb, A.A., Marai, I.F.M., Dooder, A.H. and Yousef, H.M. (1995): Effect of diet supplementation and body cooling on heat stressed Freisen calves reared under Eastern Desert of Egypt. 5th Sci. Conf. Animal Nutrition. Esmailia Univ. Vol. 1: 39-49.

Hoogwert, B.J., Laine, D.C. and Greene, E. (1986): Urine C-peptide and creatinine (Jaffe method) excretion in healthy young adults on varied diets: Sustained effects of varied carbohydrate, protein and meat content. Am.J. Clin. Nutr. 43 (3): 350.

James, E., Breazile, D.V.M., Beames, C.G. and Cardielhac, P.T. (1971): Textbook of Veterinary Physiology. Lea \& Febiger, Philadelphia, PP 480-487. 
Kalisnik, M. (1981): Stereological analysis of the thyroid gland by light microscopy. 11th. International Congress of Anatomy: Advances in Morphology of the Cell and Tissues. NewYork, Alan R.Liss Inc, 151-160.

Karnovsky, M.J. (1965): A formaldehyde - glutaraldehyde fixative of high osmolarity for use in electron microscopy. J Cell Biol 27: 137A.

King, D.B. and May, J.D. (1984): Thyroidal influence on body growth. J. Exp. Zool. 232:453.

Maile, S. (1995): Morphology of the thyroid follicular cells from adult marosets (Callithrix jaccuh). Annals of Anatomy. 177: 337-346.

Matter, B.B., Mahmoud, A.M., Kuoret, I.S. and Abou-Selim, I.A. (1995):

Effect of feeding various sources of non-protein nitrogen on performance of lactating Friesian cows. 5th Sci. Conf. Animal Nutrition, Vol 1: 1-10, Ismailia Uni.

Mollenhauer, H.H. (1964): Plastic embedding mixture for use in electron microscopy. Stain Technol. 39: 111-114.

National Research Council (N.R.C., 1985): Nutrient Requirements of Sheep. 6th Ed., National Academy Press, Washington, D.C., USA.

Panciera, D.L., Atkins, C.E., Bosa and T.K. MacEwen, E.G. (1990): Quantitative morphological study of the pitutary and thyroid glands of dogs administered L-thyroxine. Am. J. Vet. Res., 51: 27-31.

Reynolds, E.S. (1963): The use of lead citrate at high $\mathrm{pH}$ as an electronopaque stain in electron microscopy. J Cell Biol 17: 208 - 212.

SAS (1987): SAS/STAT Guide for personal computer (ver. 6 END). SAS INST., Cary, N.C.

Seljelid, R. (1965): Electron microscopic localization of acid phosphatase in rat thyroid follicle cells after stimulation with thyrotropic hormone. $\mathbf{J}$. Histochem. Cytochem. 13: 687-690.

Seljelid, R. (1967): Endocytosis in thyroid follicle cells. V. On the redistribution of cytosomes following stimulation with thyrotropic hormone.J. Ultrastruct. Res. 18: 479-488.

Shalach, D.S. and Cree, T.C. (1985): Protein utilization in growth: Effect of caloric deficiency on serum growth hormone, somatodines, total thyroxine (T4) and triidothyronine, free $\mathrm{T} 4$ index and total corticosterone. Endocrin. 17 (6): 2307.

Steel, R.G. and Torrie, J.H. (1980): Principle and procedures of statistics, A Biometrical Approach (2nd Ed.). Mc Graw-Hill Book Co. NewYork. 
Tachiwaki, O. and Wollman, S.H. (1990): Comparison of special class of epithelial cells in hyperplastic thyroids undergoing involution and in thyroid in hypophysectomized rats. Am. J. Anat. 189: 57-61.

Watkins, B.E., Nachreiner, R.F., Schmitt, S.M., Cooly, T.M. and Ullrey, D.E. (1982): Thyroid function in fed and fasted white-tailed fawns. Can. J. Zool. 60 (6): 1331.

Wetzel, B.K., Spicer, S.S., Wollman, S.H. (1965): Changes in fine structure and acid phosphatase localization in rat thyroid cells following thyrotropin admininstration. J Cell Biol 25: 593 - 619.

Wissing, S.L. (1963): The anatomy of secretion in the follicular cells of the thyroid gland. II- The effect of acute thyrotrophic hormone stimulation on the secretory apparatus. J Cell Biol 16: 93 - 117.

Wollman, S.H., Spicer, S.S., Burstone, M.S. (1964): Localization of esterase and acid phosphatase in granules and colloid droplets in rat thyroid epithelium. J. Cell Biol. 21: 191-201.

Table (2)

Growth performance of the different experimented groups.

\begin{tabular}{|l|c|c|c|c|}
\hline \multicolumn{1}{|c|}{ Items } & Group 1 & Group 2 & Group 3 & Group 4 \\
\hline - Initial body weight(Kg) & 34.40 & 34.60 & 34.60 & 34.40 \\
- Final body weight (Kg) & 44.00 & 47.80 & 49.00 & 45.70 \\
- Total body gain (Kg) & 9.60 & 13.20 & 14.40 & 11.30 \\
- Daily body gain (g/day) & $71.10^{b}$ & $97.70 a$ & $106.70 a$ & $83.70 b$ \\
-Daily feed intake (g/day) & & & & \\
$\quad$ concentrate & 500 & 500 & 500 & 500 \\
$\quad$ Roughage & 375 & 453 & 525 & 336 \\
Total & $875 b$ & $953 a$ & $1025 a$ & $836 b$ \\
-Daily iodine intake (g/day) & 2.78 & 1.02 & 1.02 & 1.02 \\
-Feed effeciency & 12.30 & 9.75 & 9.61 & 9.99 \\
$\quad$ (g feed/g gain) & 7.23 & 6.35 & 6.45 & 6.73 \\
\hline
\end{tabular}

Values with different superscript letters within the raw differ significantly $(\mathrm{P}<0.01)$. 
Table (3)

Thyroxine $\left(\mathrm{T}_{4}\right)$, thyroxine uptake ( $\mathrm{T}_{4}$ uptake), free thyroxine index (FTI), total cholesterol and glucose levels in the serum of the different groups under experiment.

\begin{tabular}{|l|c|c|c|c|c|}
\hline Item & $\begin{array}{c}\mathrm{T}_{4} \\
(\mu \mathrm{g} / \mathrm{dl})\end{array}$ & $\begin{array}{c}\mathrm{T}_{4} \text { uptake } \\
\%\end{array}$ & FTI & $\begin{array}{c}\text { Total cholesterol } \\
(\mathrm{mg} / \mathrm{dl})\end{array}$ & $\begin{array}{c}\text { Glucose } \\
(\mathrm{mg} / \mathrm{dl})\end{array}$ \\
\hline Group 1 & $4.3 \pm 2.1^{a}$ & $44.15 \pm 0.9$ & 4.3 & $87.27^{b}$ & $62.46 b$ \\
Group 2 & $4.6 \pm 0.7^{a b}$ & $42.00 \pm 1.5$ & 4.4 & $34.61^{a}$ & $91.08^{a}$ \\
Group 3 & $5.6 \pm 1.2^{b}$ & $44.35 \pm 0.1$ & 5.6 & $41.23^{a}$ & $84.02^{a}$ \\
Group 4 & $9.1 \pm 0.7^{c}$ & $46.75 \pm 15$ & 9.6 & $56.69^{a}$ & $81.08^{a}$ \\
\hline
\end{tabular}

Values marked with a different superscript letters within the column differ significantly.

\section{Table (4)}

Volume percentages $(\mathrm{Vp})$ of the interstitial tissue, follicular colloid and follicular epithelium as well as the folicular epithelial height in the different examined groups.

\begin{tabular}{|l|c|c|c|c|}
\hline Treated groups & Groupl & Group2 & Group3 & Group4 \\
\hline Interstitial tissue $(\mathrm{Vp})$ & $29.30 \pm 0.60^{a}$ & $24.46 \pm 0.17^{b}$ & $20.45 \pm 0.23^{c}$ & $33.08 \pm 0.52^{d}$ \\
Follicular colloid $(\mathrm{Vp})$ & $22.21 \pm 0.90^{a}$ & $40.46 \pm 1.83^{b}$ & $29.32 \pm 1.74^{c}$ & $11.19 \pm 1.92^{d}$ \\
Follicular epithelium $(\mathrm{Vp})$ & $48.49 \pm 0.75^{a}$ & $35.08 \pm 1.00^{b}$ & $50.23 \pm 1.98^{c}$ & $55.47 \pm 1.72^{d}$ \\
Follicular cell height $(\mu \mathrm{m})$ & $14.11 \pm 3.23^{a}$ & $08.13 \pm 1.89^{b}$ & $14.66 \pm 2.55^{a}$ & $18.78 \pm 2.69^{c}$ \\
\hline
\end{tabular}

*Values with different superscript letters in the same raw differ significantly $(\mathrm{P}<0.01)$. 

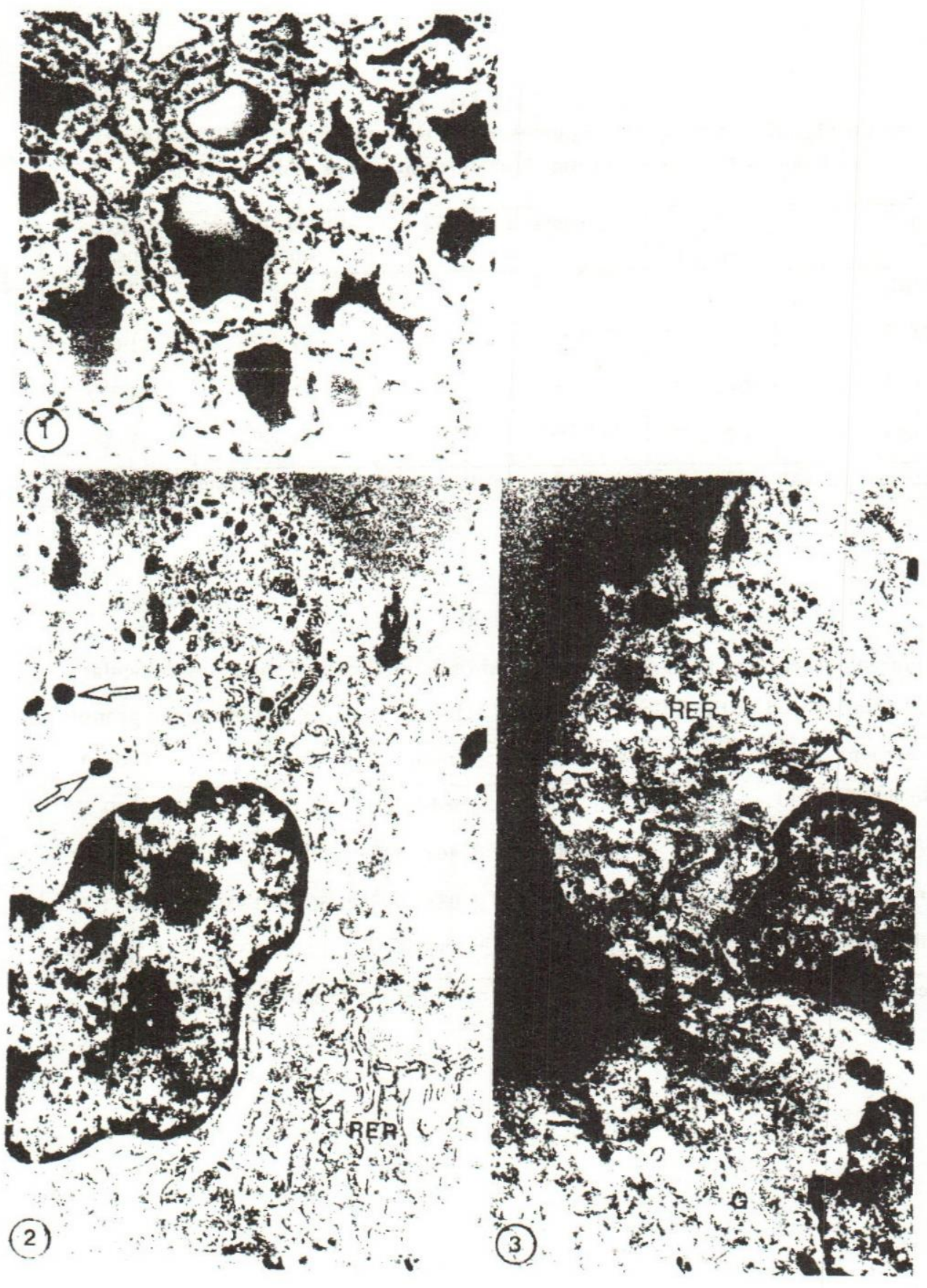


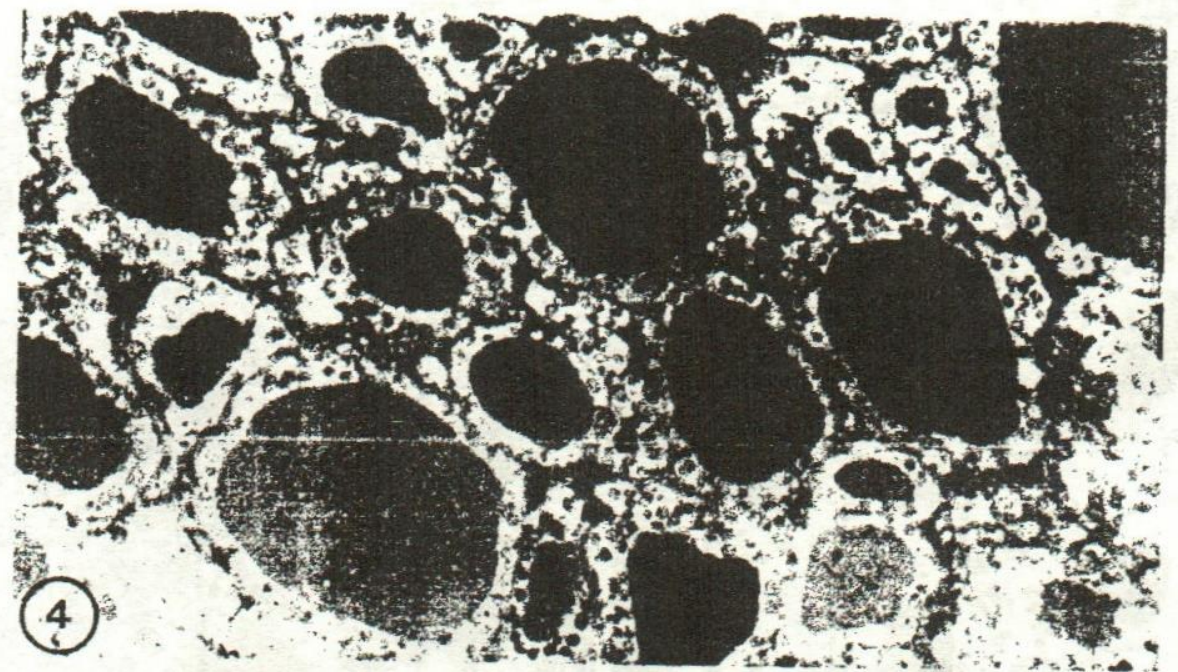

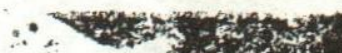

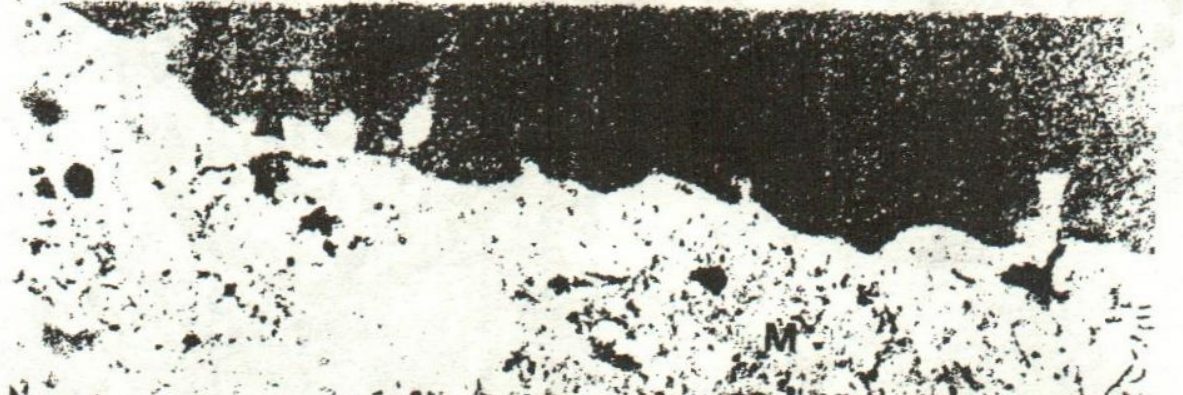

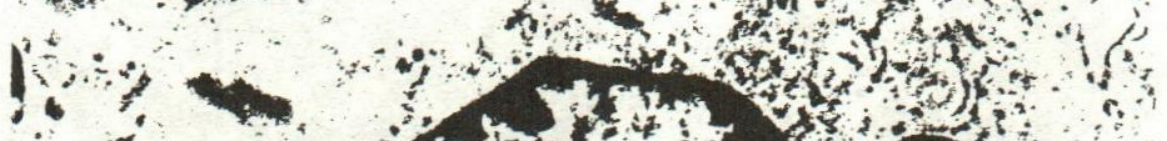
and

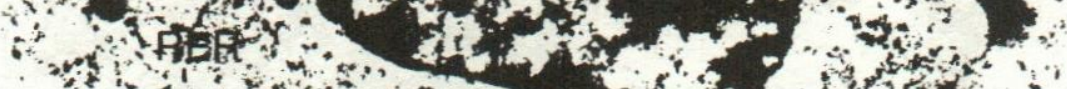
(5) 


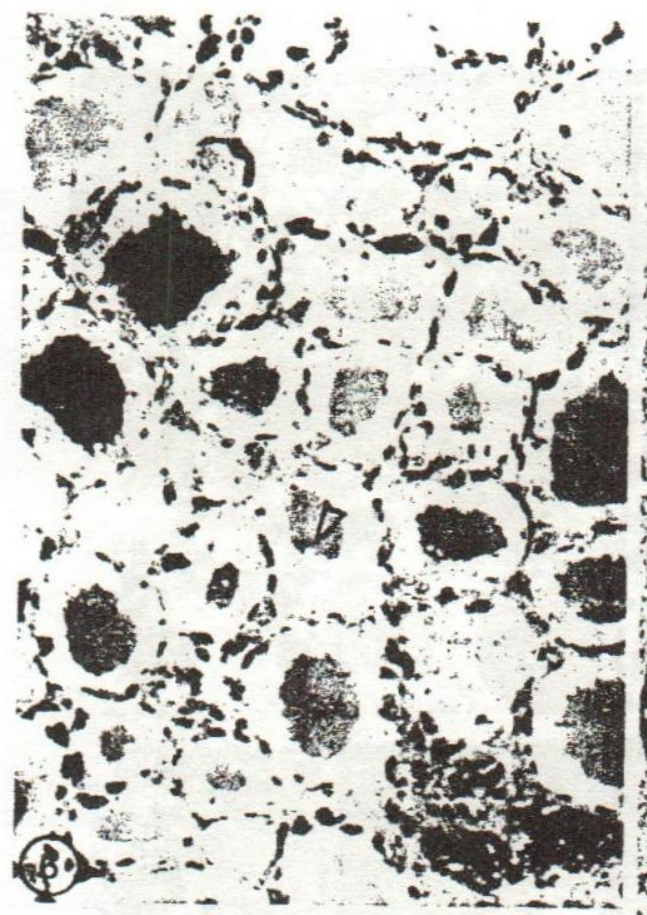

(4) ofon

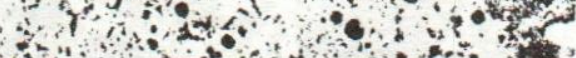

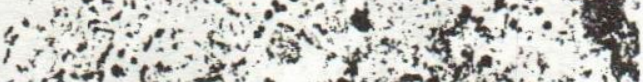
$40+00$ and 3 int

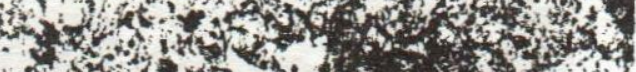

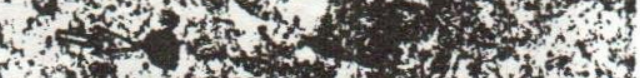

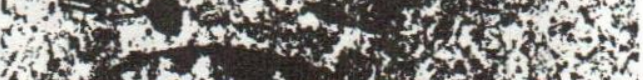

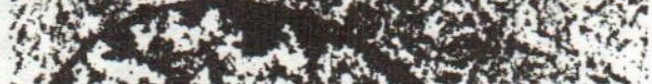

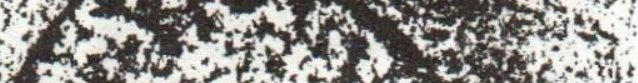

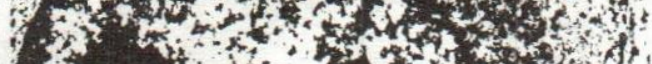
(1)

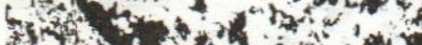

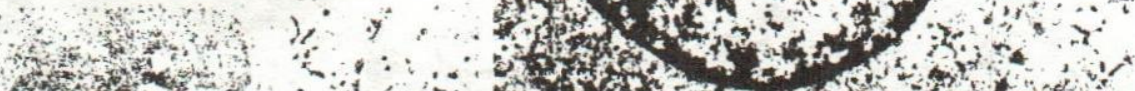

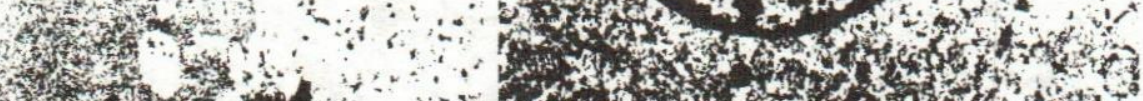

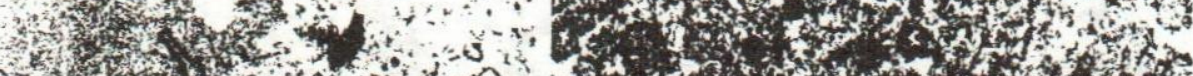

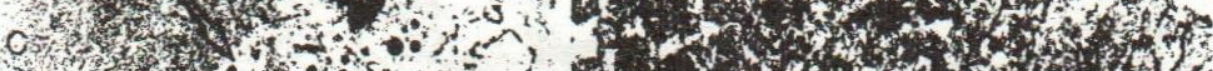

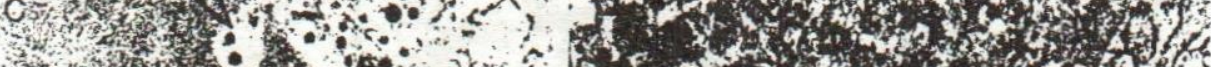
(N)

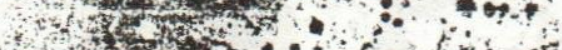

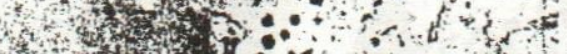

(1)

40 (n)

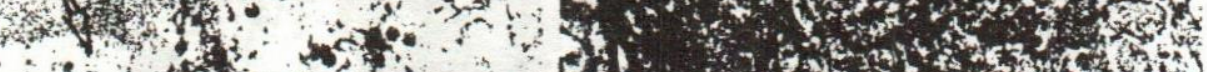

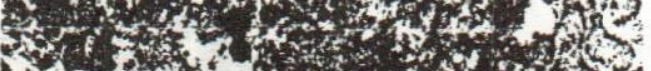

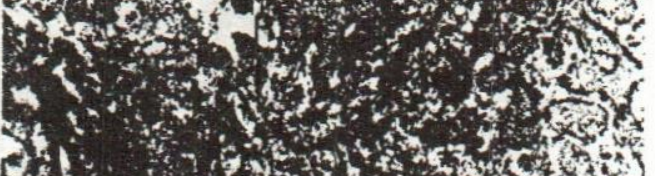

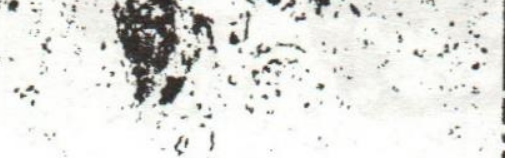

(7)

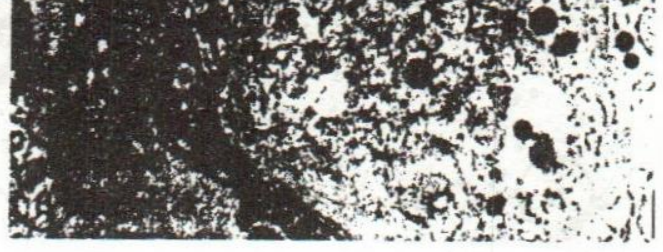




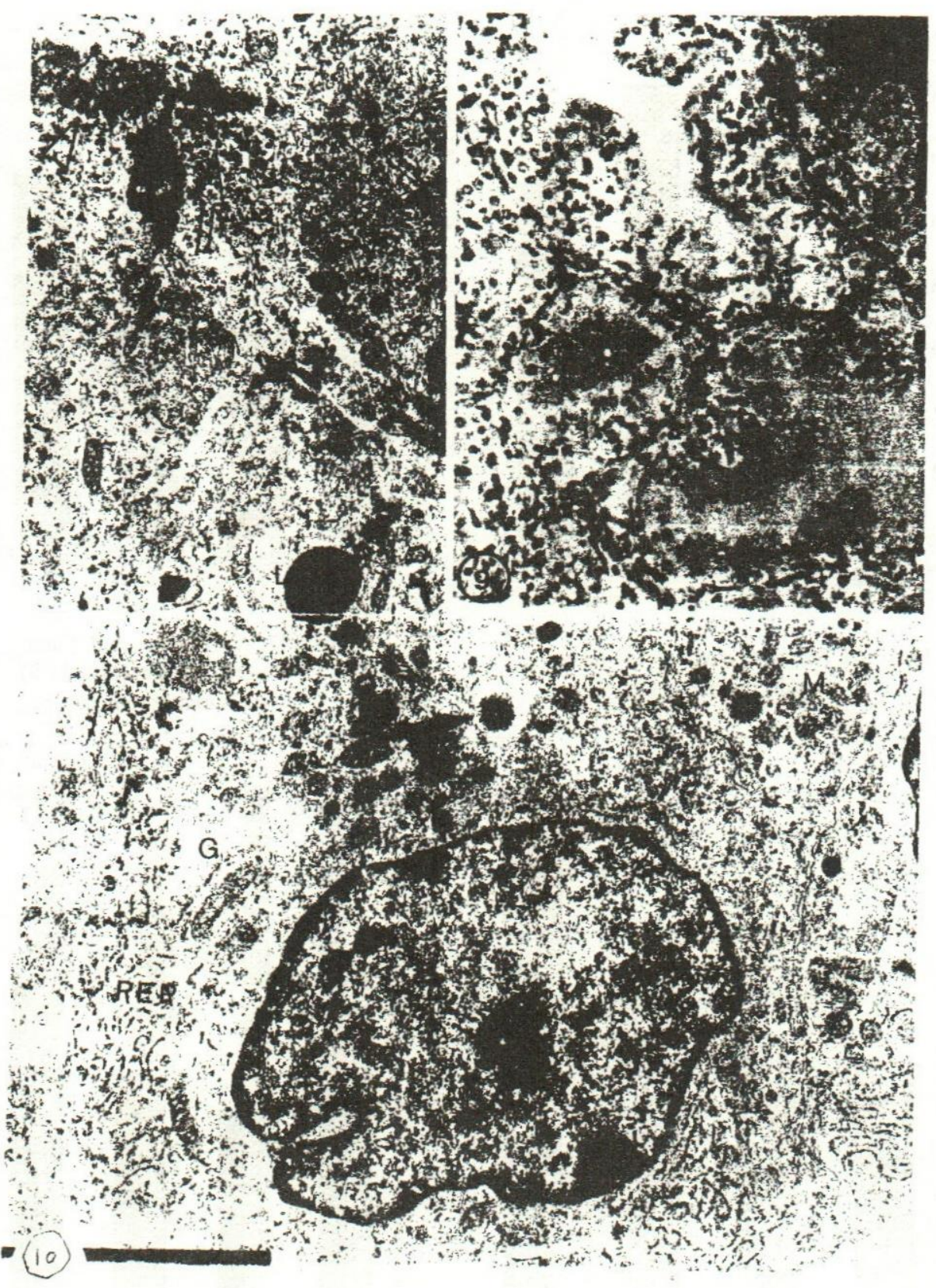


Fig. (11): Total body weight gain $(\mathrm{Kg})$ estimated in different groups.
Fig. (12): Feed effeciency ( $\mathrm{g}$ feed/g gain) in different groups

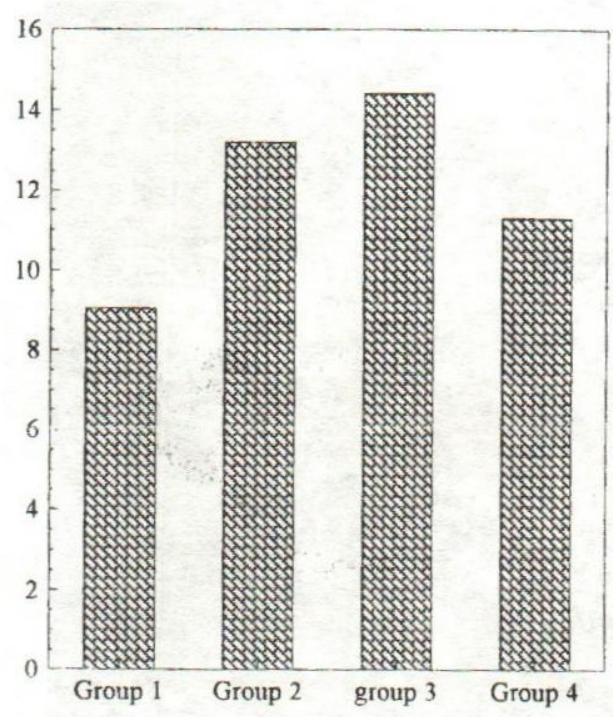

Fig. (13): Serum thyroxine (T4) level (ug/dl) in different groups.

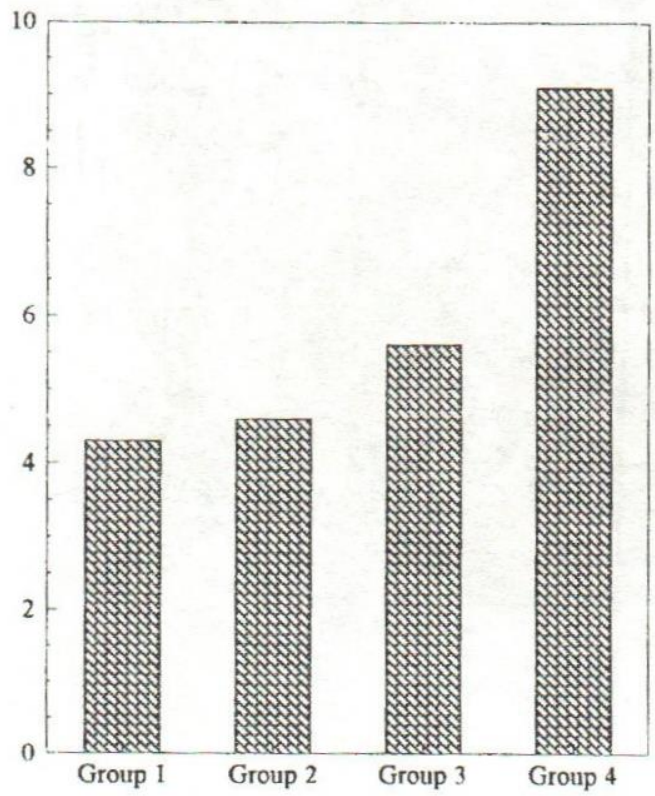

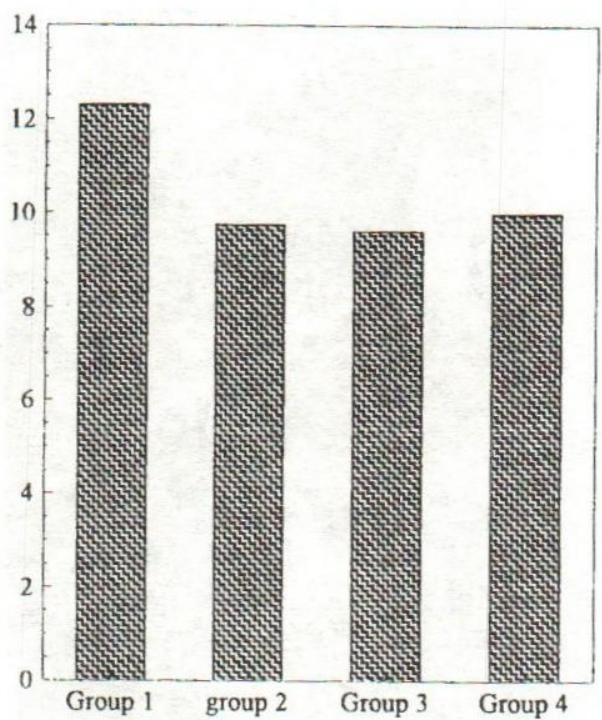

Fig. (14): Serum glucose (G) and total cholesterol ( $\mathrm{T} \mathrm{Ch})$ levels in different groups.

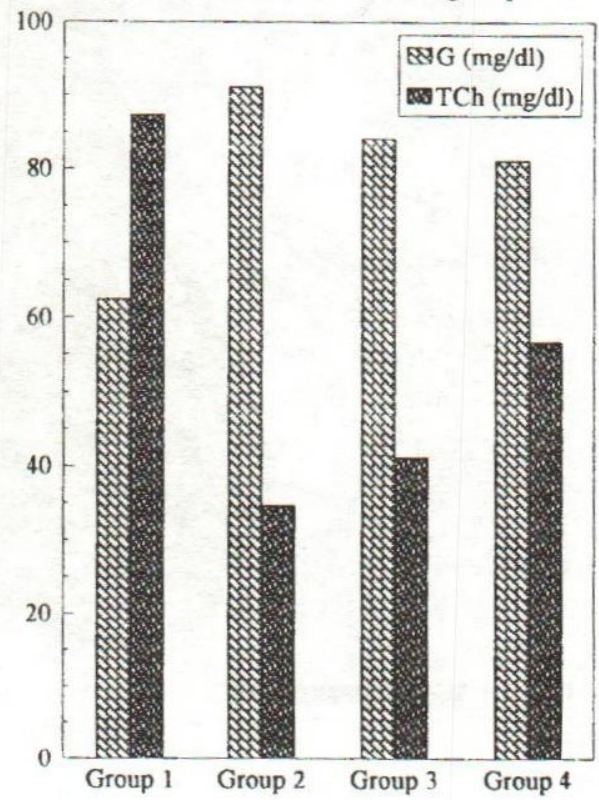


Fig. (15): Volume percentages of interstitial tissue (IT), follicular colloid (FC) and follicular epithelium (FE) in different groups.

Fig. (16): Follicular epithelial height (um) in different groups.
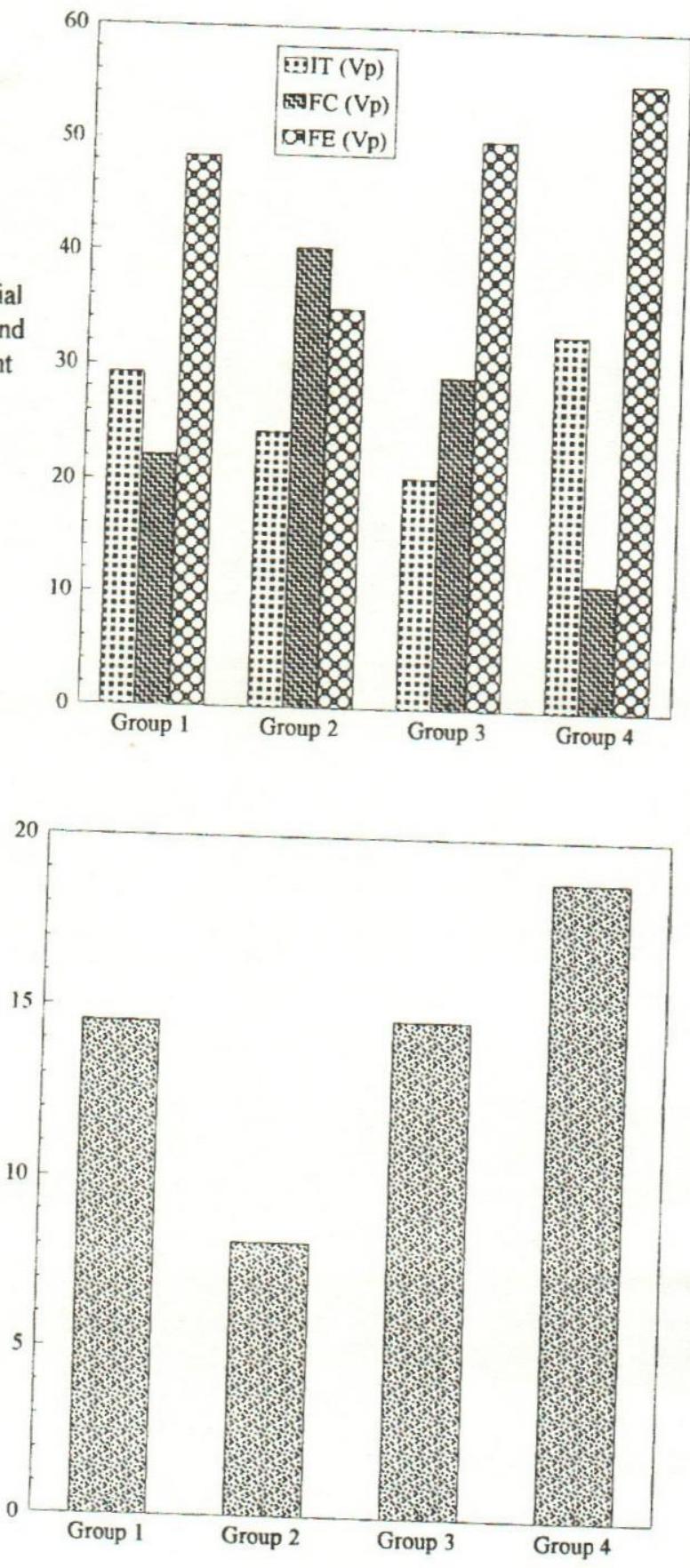
